\title{
Estimation of Optimum Tilt Angle of PV Panel for Maximum Energy Harvesting
}

\author{
K. Parkavi Kathirvelu, B. Viswanathan \\ Electrical and Electronics Engineering SASTRA University, Thanjavur-613401, India
}

\begin{tabular}{l}
\hline \hline Article Info \\
\hline Article history: \\
Received May 18, 2016 \\
Revised Jul 22, 2016 \\
Accepted Aug 10, 2016 \\
\hline
\end{tabular}

\section{Keyword:}

Maximum energy harvesting Optimum tilt angle

Seasonal tilt

Fixed tilt

Isotropic models

Anisotropic models

\begin{abstract}
In solar energy conversion system harvesting of maximum energy is necessary in order to maximize the utilization of available energy. The maximum energy from the solar panel can be extracted by keeping solar panel in an optimum tilt angle. Various approaches are available to find optimum tilt condition of the solar panel. In this work two different positions of the panel such as fixed tilt, seasonal tilt were analyzed using isotropic and anisotropic models. Among the various models available in the above said broad category six models such as Liu-Jordan, Koronokis Model, Badescu model, Hay and Davis model, Reindel model, Hay\&Davis and Reindel \& Klucher combined model are incorperated to predict the monthly average of daily global solar irradiation of the inclined panels held in SASTRA University, Thanjavur (India) location. Statistical tests have been performed in order to evaluate the consequences predicted by the models with the experimental results. Finally a detailed comparison between fixed tilt and seasonal tilt of the panel has been carried out and the suitable model for this location is also suggested.
\end{abstract}

Copyright (C) 2016 Institute of Advanced Engineering and Science. All rights reserved.

\section{Corresponding Author:}

Parkavi kathirvelu, School of Electrical and Electronics Engineering,

SASTRA University,

Tirumalaisamudram, Thanjavur.

Email: to_parkavi@eee.sastra.edu

\section{INTRODUCTION}

Deteriorating of fosil fuels like coal, natural gas, crude oil and the environmental pollution produced by them increases the utilization of natural energy resources like wind, solar, biomass and tidal. Among the available various energy sources PV energy is eternal, unpolluted and freely available and can be easily stored. The energy received by the solar panel mainly depends on the solar irradiation incident on it . The major shortcoming of the solar power conversion is its poor efficiency and usually between $16 \%-18 \%$ [1]. One way to overcome the above shortcoming is to fix the solar panels properly in order to obtain the maximum energy from the sun [2]-[4]. Hence the main objective of the panel installation is to fix the panel in an appropriate orientation and tilt angle to acquire the maximum energy. Tracking mechanisms are used to keep the panel in optimum position to obtain the maximum energy from the sun. Fixed tilt, seasonal tilt and servo tracking are the three major approaches used for PV panel installation. If the Panels are installed to meet out large power requirement fixed tilt is preferred method due to its low running cost. In servo tracking method in order to acquire maximum energy from the solar panel, the panel is rotated in two axes with the help of servo motors. This tracking mechanism is not cost effective and hence suitable for very low power applications only. The seasonal tilt method is employed in the places where there is a difference in the irradiance between summer and winter season also it is beneficial to change the tilt angle seasonally. In this method panel is tilted for four different seasons in a year. This method is preferred owing to its very low installation cost and comparatively high efficiency [5]. 
The solar irradiation on the inclined panel consists of three components such as diffused, beam and Reflected irradiations. There are two different models named isotropic and anisotropic are generally used to find out the total global irradiation on the inclined surface [6]. In all these models calculation of beam and reflected radiations are identical but diffused radiation varies according to the model. In isotropic models diffused radiation is considered identical over the sky dome on the other hand in anisotropic models it consists of isotropic, circum solar and horizontal brightening components.Generally the places which are situated in northern hemisphere, the optimum collector orientation is towards south facing. Several research studies have indicated that fixing the solar panels in the fixed tilt rely upon the latitude of the place. Duffie and Beckman [7], El-Sebaii et al [8], Danny H.W. Li et al., [9] proposed that optimum tilt angle of the panel should be in the latitude angle. Gladius Lewis [10] opted optimum tilt angle $\beta_{\text {opt }}$ is equal to Latitude angle $(\Phi) \pm 8^{\circ}$ and Yellott [11] suggested the optimum tilt angle of the panel should be Latitude angle $(\Phi) \pm 20^{\circ}$. Lunde and Gerg [12] proposed optimum tilt angle of the solar panel lies in the range of Latitude angle $\pm 15^{\circ}($ $\Phi \pm 15^{\circ}$ ). Morse and Ezarnecki suggested the optimum tilt angle should be 0.9 times higher than the latitude angle. In this work fixed tilt is employed by keeping the solar panel at latitude angle for to take measurements and the results are analyzed.

The main intent of this work is to analyze the total solar radiation incident on the PV panel at SASTRA location by considering the two different cases like (i) fixed tilt with the tilt angle of $10.78^{\circ} \mathrm{N}$ (latitude) and (ii) seasonal tilt in which panel is rotated for four seasons in a year. In this paper various isotropic and anisotropic models namely Liu-Jordan, Koronokis Model, Badescu model, Hay and Davis model, Reindel model and Hay\&Davis,Reindel \& Klucher combined model are used to find the total solar irradiation received by the panel for the cases which are mentioned above. The solar irradiations obtained from these models are compared with measured data in real time using statistical tests and the results are also analyzed. Finally the performance of fixed tilt and seasonal tilt of the panels are also compared.

\section{MATERIALS AND METHODOLOGY}

\subsection{Test location}

SASTRA UNIVERSITY, Thanjavur is located in $10.78^{\circ} \mathrm{N}$ latitude, $79.13^{\circ} \mathrm{E}$ longitude and $57 \mathrm{~m}$ altitude. It has a tropical climatic condition. The summer season from March to May is very hot and dry, June marks the commencement of Monsoon season and it lasts till September and heavy rainfall is experiences in winters from the month of December to February. Normal Temperature in this location ranges from $28^{\circ} \mathrm{C}$ to $37^{\circ} \mathrm{C}$ during these months. .For experimental verification of these work 732 modules each rated $250 \mathrm{~W}$ place in electrical building SASTRA which supplies 183KW have been considered.

\subsection{Extra terrestrial solar irradiation on the horizontal surface}

The extra terrestrial solar irradiation is the irradiance available outside the earth's atmosphere. Measurement of the intensity of extraterrestrial solar radiation is difficult because it varies with the distance between the Earth and Sun. The following arithmetical relationship gives the monthly average of daily extra terrestrial radiation [13].

$$
H o=24 / \pi s(1+0.033 \cos (360 d / 365))[\cos \varphi \cos \delta \sin \omega+\omega \sin \varphi \sin \delta]
$$

where ' $\mathrm{s}$ ' is the solar constant and its value is $1.367 \mathrm{KW} / \mathrm{m}^{2}$, ' $\mathrm{d}$ ' is day of the year, ' $\omega$ ' is the sunshine hour angle , ' $\varphi$ ' is the latitude angle and ' $\delta$ ' is the declination angle.

$$
\begin{aligned}
\omega & =\cos ^{-1}[\tan \delta \tan \varphi] / \tan \delta \tan \varphi / \leq 1 \\
& =\pi / \tan \delta \tan \varphi />1
\end{aligned}
$$

Solar declination angle [12] is given as

$$
\delta=23.45 \sin [2 \pi(284+d) / 365]
$$

Extra terrestrial irradiation is used to find the value of clearness index $K_{T}$ which is the ratio of global solar irradiation and extra terrestrial solar radiation and it is used to calculate diffused radiation. 


$$
K_{T}=H_{g} / H o
$$

where $\mathrm{H}_{\mathrm{g}}$ is the global solar irradiation and $\mathrm{H}_{\mathrm{o}}$ is the extra terrestrial radiation

$$
\text { If } \omega<81.4^{\circ} \text { and } 0.3<K_{T}<0.8
$$

The diffused solar radiation $\mathrm{H}_{\mathrm{d}}$ is given as

$$
\frac{H_{d}}{H_{g}}=1.391-3.650 K_{T}+4.189 K_{T}^{2}-2.13 K_{T}^{3}
$$

If $\omega>81.4^{\circ}$ and $0.3<K_{T}<0.8$

$$
H_{d} / H_{g}=1.311-3.022 K_{T}+3.427 K_{T}^{2}+1.821 K_{T}^{3}
$$

\subsection{Solar radiation on the inclined surface}

Global solar irradiation for the horizontal surface can be obtained from metrological station but for an inclined surface it cannot be directly acquired. Various models are used to obtain the irradiation of inclined surface. Solar irradiation is the sum of beam radiation, diffused radiation and reflected radiation. The undisturbed solar radiation fall directly on the panel is known as direct radiation. The solar radiation which is scattered, reflected or absorbed by dust, water vapor, clouds or pollutants produces the diffused radiation. The solar panel receives the radiation which is reflected by the surface of the earth, trees, terrain or building is known as reflected radiation. This radiation details are very much essential for the design solar panel, mounted on the inclined surface. The total incident radiation on the panel is given by [14]-[16].

$$
H_{\text {Tilt }}=H_{\text {beam }}+H_{\text {difused }}+H_{\text {reflected }}
$$

where, $\mathrm{H}_{\text {Tilt }}$ is Total incident solar radiation on the inclined panel, $\mathrm{H}_{\text {beam }}$ is beam solar irradiation, $\mathrm{H}_{\text {diffused }}$ is Diffused solar irradiation and $\mathrm{H}_{\text {reflected }}$ is reflected solar irradiation.

$$
H_{\text {Tilt }}=\left(H_{g}-H_{d}\right) R_{b}+H_{d} R d+H_{g} \rho R_{r}
$$

where $R_{b}, R_{d}$ and $R_{r}$ are the beam, diffused and radiation coefficients and given as follows

$$
R_{b}=\frac{\cos (\varphi-\beta) \cos \delta \sin \omega_{S}^{\prime}+\omega_{S}^{\prime} \sin (\varphi-\beta) \sin \delta}{\cos \varphi \cos \delta \omega_{S}^{\prime}+\omega \sin \varphi \sin \delta}
$$

where $\beta$ is the tilt angle of the inclined panel and $\omega_{\mathrm{s}^{\prime}}$ is the sunshine hour angle for tilted surface. Sunshine hour angle for tilted surface is given as

$$
\begin{aligned}
& \omega_{S, \text { Tilt }}=\cos ^{-1}[-\tan \delta \tan (\varphi-\beta)] \\
& \omega_{S}^{\prime}=\min \left(\omega_{S, \text { Tilt }}, \omega\right) \\
& R_{d}=(1+\cos \beta) / 2 \\
& R_{r}=(1-\cos \beta) / 2
\end{aligned}
$$

\subsection{Mathematical models for determining the optimum tilt angle}

Table 1 deliberates the comparison of different isotropic and anisotropic models used to find the irradiation received by the PV panel. In these models $\mathrm{LJ}, \mathrm{Ba}$, Ko models are best fit for finding total irradiation in cloudy sky conditions while at the same time anisotropic models like HD, Re and HDRKC models are best suited for clear sky conditions. In isotropic models the total irradiation on the tilted panel is

Estimation of Optimum Tilt Angle of PV Panel for Maximum Energy Harvesting (K. Parkavi Kathirvelu) 
composed of beam, diffused and reflected radiation while Horizon brightening and circum solar components are not considered in this models. In HD model circum solar component is incorporated along with isotropic components. In the Re model Horizon brightening and circum solar components both are taken into account along with isotropic components. The HDRKC model is similar to Re model and it was developed by combining the HD model, Re model and Klucher model.

Table 1. Comparison of different isotropic and anisotropic models used to find total irradiation received by

\begin{tabular}{ccccc} 
Model & $\begin{array}{c}\text { Developed } \\
\text { year }\end{array}$ & Type & The PV panel \\
\hline LJ & 1962 & Isotropic & $H_{T}=H_{b} R_{b}+H_{g} \rho\left(\frac{1-\cos \beta}{2}\right)+H_{d}\left(\frac{1+\cos \beta}{2}\right)$ \\
Ko & 1986 & Isotropic & $H_{T}=H_{b} R_{b}+H_{g} \rho\left(\frac{1-\cos \beta}{2}\right)+H_{d}\left(\frac{2+\cos \beta}{3}\right)$ \\
Ba & 2002 & Isotropic & $H_{T}=H_{b} R_{b}+H_{g} \rho\left(\frac{1-\cos \beta}{2}\right)+H_{d}\left(\frac{3+\cos 2 \beta}{4}\right)$ \\
HD & 1980 & anisotropic & $H_{T}=\left(H_{b}+H_{d} A\right) R_{b}+H_{g} \rho\left(\frac{1-\cos \beta}{2}\right)+H_{d}\left(\frac{1+\cos \beta}{2}\right)(1-A)$ \\
Re & 1990 & Anisotropic & $H_{T}=\left(H_{b}+H_{d} A\right) R_{b}+H_{g} \rho\left(\frac{1-\cos \beta}{2}\right)+H_{d}\left(\frac{1+\cos \beta}{2}\right)(1-A)\left[1+\sqrt{\frac{H_{b}}{H_{g}}} \sin ^{3}\left(\frac{\beta}{2}\right)\right]$ \\
HDRKC & 2015 & anisotropic & $H_{T}=\left(H_{b}+H_{d} A\right) R_{b}+H_{g} \rho\left(\frac{1-\cos \beta}{2}\right)+H_{d}\left(\frac{1+\cos \beta}{2}\right)(1-A)\left[1+\sin ^{3}\left(\frac{\beta}{2}\right)\right]$ \\
\hline
\end{tabular}

Isotropic and anisotropic are the two diverse approaches used to model the diffused radiation. For finding total solar radiation various models are available in which Liu-Jordan (LJ), Koronokis Model (Ko), Badescu model (Ba), Hay and Davis model (HD), Reindel model and Hay\&Davis and Reindel \& Klucher (HDRKC) combined model are considered in this work [17]-[23].

\subsection{Models evaluation}

The predicted values of solar irradiation using the above six models can be validated by using the real time measured data. Following four statistical tests known as Mean Absolute Percentage error test, Mean bias error test, Root mean square error test and t-statistical tests [23] are performed for the estimation of real time solar irradiation.

\section{Mean Absolute Percentage error test (MAPE test)}

It is a most common method of evaluation used in the forecasting. It estimates the average of unsigned percentage error.

$$
\text { MAPE }=\left(\frac{1}{n} \sum_{i=1}^{n} \frac{\left|H_{\text {measured }}-H_{\text {predicted }}\right|}{\left|H_{\text {measured }}\right|}\right) * 100
$$

2. Mean Bias error test (MBE test)

MBE test assessed the difference of predicted and measured values

$$
M B E=\frac{1}{n} \sum_{i=1}^{n}\left|H_{\text {measured }}-H_{\text {predicted }}\right|
$$

3. Root mean square error test (RMSE test) measured.

It directly gives the difference between the values predicted by a model and the value actually

$$
R M S E=\sqrt{\frac{1}{n}} \sum_{i=1}^{n}\left|H_{\text {predicted }}-H_{\text {measured }}\right|
$$


4. t-statistics (t-stat)

The t-test correlates the actual variation between two means in relation to the variation in the data.

$$
t-s t a t=\sqrt{\frac{(n-1) M B E^{2}}{R M S E^{2}-M B E^{2}}}
$$

\section{ANALYSIS AND INFERENCES}

Input parameters for the computation of solar radiation incident on the inclined panel are given in the Table 2. From this it is inferred that declination angle $(\delta)$ varies between -22.09 to +23.01 according to Cooper's model. For SASTRA location maximum sunshine angle obtained is 94.63 and minimum is 85.38 .

In this work using the data given in the above table both the types of tilting methods such as fixed tilt and seasonal tiltchave been analyzed.

Table 2. Input parameters used for the calculation of solar irradiation on tilted surface at SASTRA, India

\begin{tabular}{|c|c|c|c|c|c|c|c|}
\hline Months & $\begin{array}{l}\text { Day } \\
\text { of the } \\
\text { year } \\
(\mathrm{N})\end{array}$ & $\begin{array}{l}\text { Declination } \\
\text { angle }(\delta)\end{array}$ & $\begin{array}{c}\text { Sunshine } \\
\text { angle }\left(\omega_{\mathrm{S}}\right)\end{array}$ & S(hours) & $\mathrm{S}_{\max }($ hours) & $\frac{S}{S_{\max }} \%$ & $\begin{array}{l}\text { Global solar } \\
\text { irradiation on } \\
\text { flat surface } \\
\text { (G) }\end{array}$ \\
\hline January & 1 & -22.90 & 85.38 & 9 & 11.35 & 0.7621 & 4.64 \\
\hline February & 32 & -17.43 & 86.57 & 10 & 11.51 & 0.8314 & 5.64 \\
\hline March & 60 & -8.25 & 88.41 & 10 & 11.75 & 0.8059 & 6.38 \\
\hline April & 91 & 3.997 & 90.76 & 10 & 12.07 & 0.8011 & 5.97 \\
\hline May & 121 & 14.83 & 92.88 & 9 & 12.35 & 0.7303 & 5.77 \\
\hline June & 152 & 21.93 & 94.39 & 7 & 12.55 & 0.5378 & 5.41 \\
\hline July & 182 & 23.01 & 94.63 & 7 & 12.58 & 0.4745 & 5.16 \\
\hline August & 213 & 17.82 & 93.50 & 6 & 12.43 & 0.5032 & 5.32 \\
\hline September & 244 & 07.68 & 91.47 & 7 & 12.06 & 0.544 & 5.49 \\
\hline October & 274 & -4.19 & 89.20 & 6 & 11.86 & 0.5286 & 4.51 \\
\hline November & 305 & -15.29 & 87.016 & 6 & 11.57 & 0.5263 & 3.93 \\
\hline December & 335 & -22.0 & 85.58 & 7 & 11.38 & 0.5711 & 4.10 \\
\hline
\end{tabular}

\subsection{Case study (i) fixed tilt}

Using the above mentioned models for the solar panel placed in latitude angle, irradiation has been predicted from the month of January to December 2015 and is given in the Table 3. The irradiation received by the PV panel has been measured using solarimeter and it has been given in Table 3. From Figures 1, 2, 3 and 4 it is observed that MAPE test shows very high deviation in Hay and Davis model (8.65\%) and very low deviations in Liu-Jordan model (6.10\%). MBE varies between $0.3171 \mathrm{kWh} / \mathrm{m}^{2}$-day for LJ model and 0.4380 $\mathrm{kWh} / \mathrm{m} 2$-day for HD model. HD got very high RMSE value of $0.6293 \mathrm{kWh} / \mathrm{m}^{2}$-day and LJ got $0.5260 \mathrm{kWh} / \mathrm{m}^{2}$-day.simlarly LJ model has shown very low t-test value of 2.506 and HD model has given very high t-stat value of 3.215. By comparing all the deviations LJ model gives less deviation in the entire test hence this model is best suited for SASTRA location.

Table 3. Estimated monthly average of daily solar irradiation on the solar panel in the fixed tilt using different models

\begin{tabular}{|c|c|c|c|c|c|c|c|}
\hline \multirow[b]{2}{*}{ Months } & \multicolumn{6}{|c|}{ Predicted solar irradiation for fixed tilt of the pv panel using different models } & \multirow{2}{*}{$\begin{array}{c}\text { irradiation } \\
\text { measured } \\
\text { from the PV } \\
\text { panel }\end{array}$} \\
\hline & $\begin{array}{c}\text { Liu- } \\
\text { Jordan }\end{array}$ & $\begin{array}{l}\text { Koronokis } \\
\text { Model }\end{array}$ & $\begin{array}{c}\text { Badescu } \\
\text { Model }\end{array}$ & $\begin{array}{c}\text { Hay and } \\
\text { Davis Model }\end{array}$ & $\begin{array}{l}\text { Reindl } \\
\text { Model }\end{array}$ & $\begin{array}{c}\text { Hay and } \\
\text { Davis,Reindl and } \\
\text { klucher model }\end{array}$ & \\
\hline January & 5.03 & 5.04 & 5.02 & 5.80 & 5.32 & 5.35 & 5.24 \\
\hline February & 6.06 & 5.94 & 5.91 & 5.80 & 6.15 & 6.15 & 6.1 \\
\hline March & 6.65 & 6.66 & 6.64 & 7.19 & 6.72 & 6.71 & 6.53 \\
\hline April & 5.93 & 5.94 & 5.91 & 6.28 & 5.95 & 5.94 & 6.1 \\
\hline May & 5.57 & 5.58 & 5.55 & 5.82 & 5.53 & 5.53 & 6.2 \\
\hline June & 6.27 & 6.24 & 6.24 & 6.44 & 6.19 & 6.19 & 5.8 \\
\hline July & 4.90 & 4.95 & 4.93 & 5.06 & 4.84 & 4.84 & 5.23 \\
\hline August & 5.01 & 5.01 & 5.03 & 5.22 & 4.99 & 4.46 & 5.3 \\
\hline September & 5.53 & 5.53 & 5.50 & 5.83 & 5.54 & 5.54 & 4.7 \\
\hline October & 4.58 & 4.58 & 4.55 & 4.56 & 4.92 & 4.92 & 4.12 \\
\hline November & 4.10 & 4.11 & 4.08 & 4.31 & 4.11 & 4.10 & 3.98 \\
\hline December & 3.33 & 3.33 & 3.51 & 3.61 & 3.38 & 3.38 & 3.2 \\
\hline Average & 5.25 & 5.24 & 5.24 & 5.49 & 5.31 & 5.26 & 5.20 \\
\hline
\end{tabular}

Estimation of Optimum Tilt Angle of PV Panel for Maximum Energy Harvesting (K. Parkavi Kathirvelu) 


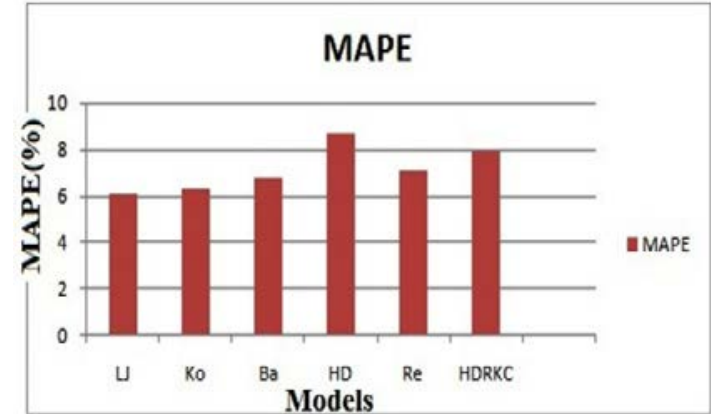

Figure 1. Comparison of MAPE test for all six model

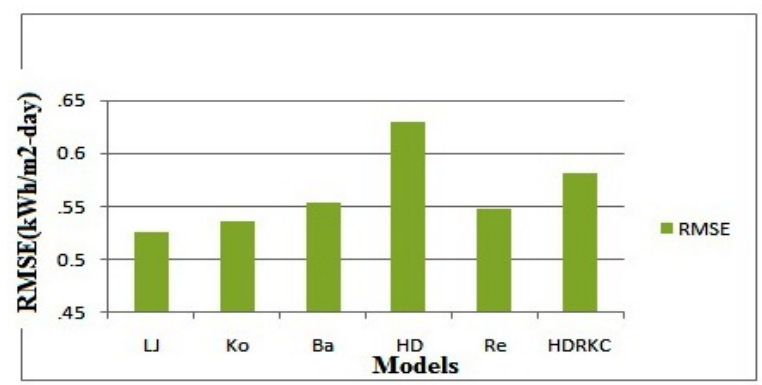

Figure 3. Comparison of RMSE test for all six models

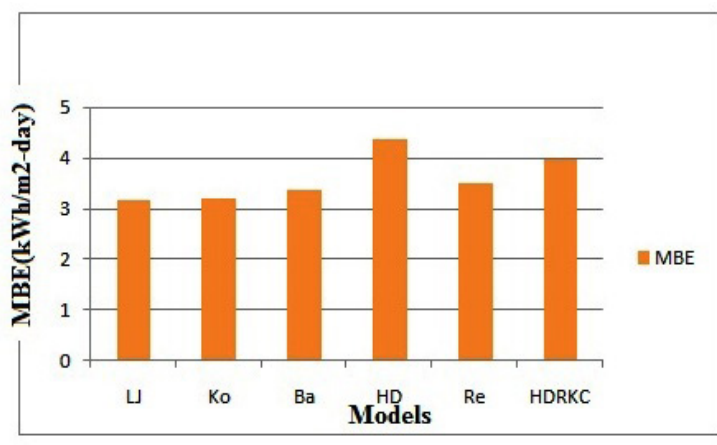

Figure 2. Comparison of MBE test for all six models

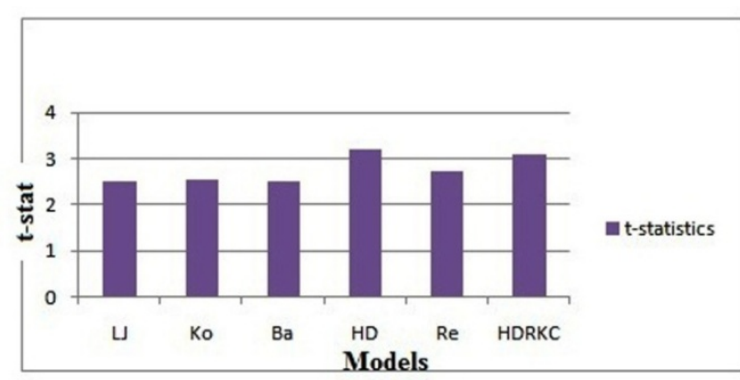

Figure 4. Comparison of t-statistics test for all six Models

\subsection{Case study (ii) seasonal tilt}

In this method all the twelve months of a year is divided into four seasons as winter, spring, summer and autumn. Optimum tilt angle and irradiation are calculated for these four seasons using the above mentioned six models and given in Table 4, Figures 5, 6, 7 and 8 shows the prediction of optimum tilt angle for four different seasons. From the results it has been concluded that optimum tilt angle varies in each season and hence the solar panel can be tilted four times in a year based on the season for better performance in SASTRA location.

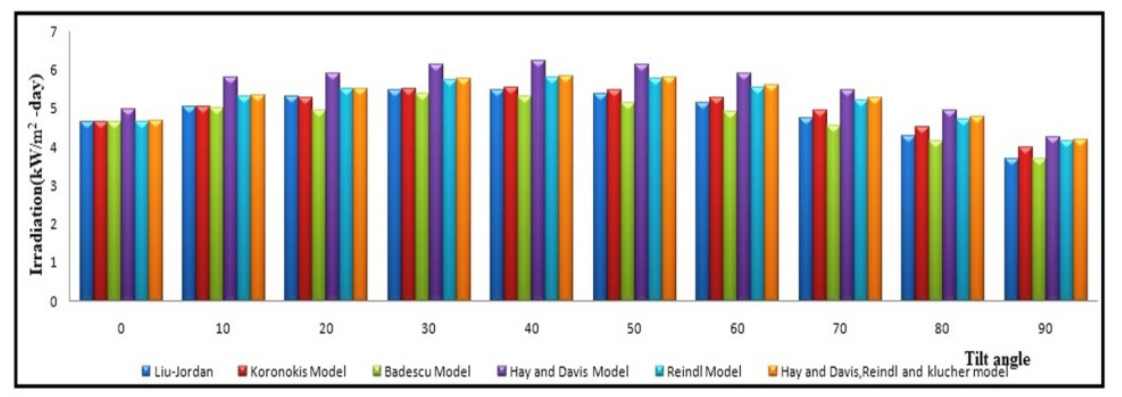

Figure 5. Comparison of Monthly average of daily global irradiation for different tilt angle in the month of January (winter) 


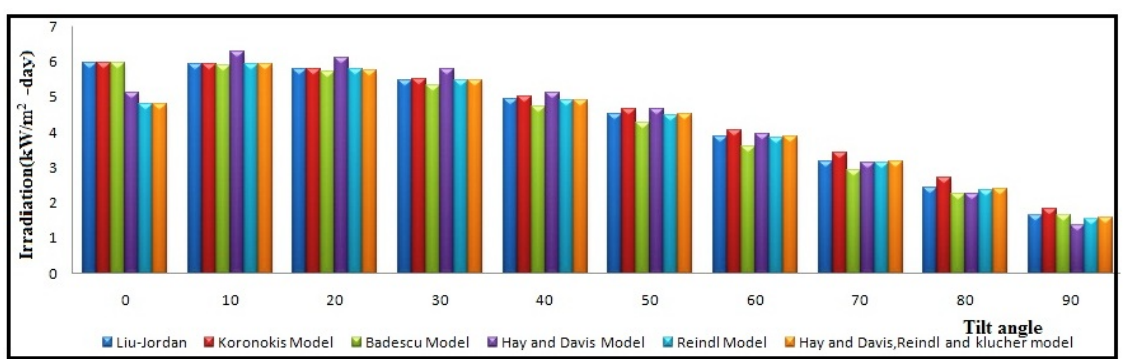

Figure 6. Comparison of Monthly average of daily global irradiation for different tilt angle in the month of March (spring)

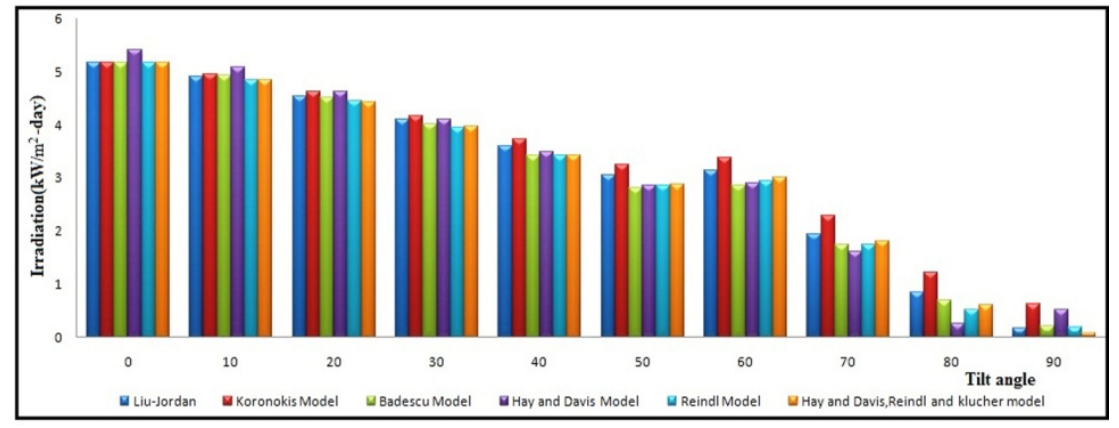

Figure 7. Comparison of Monthly average of daily global irradiation for different tilt angle in the month of July (summer)

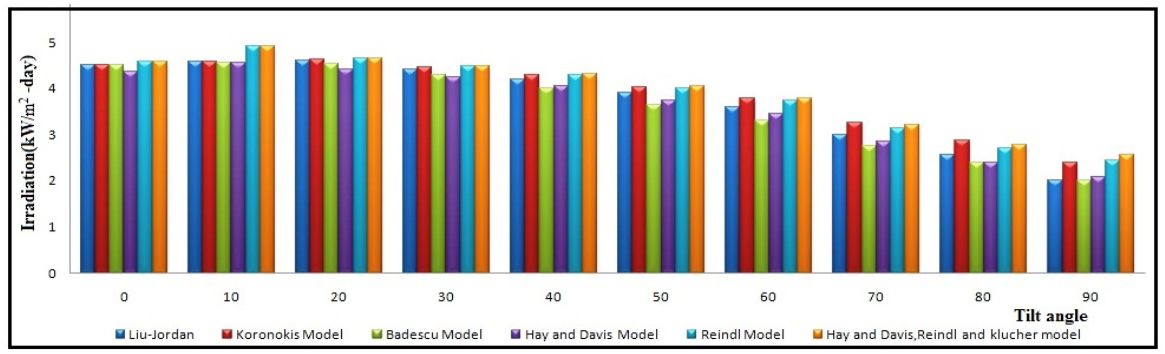

Figure 8. Comparison of Monthly average of daily global irradiation for different tilt angle in the month of October (autumn)

Table 4. Monthly average daily global irradiation for optimum tilt angle using isotropic and anisotropic models

\begin{tabular}{|c|c|c|c|c|c|c|c|c|c|c|c|c|}
\hline \multirow[b]{2}{*}{ Months } & \multicolumn{2}{|c|}{ Liu-Jordan } & \multicolumn{2}{|c|}{ Koronokis Model } & \multicolumn{2}{|c|}{ Badescu Model } & \multicolumn{2}{|c|}{$\begin{array}{l}\text { Hay and Davis } \\
\text { Model }\end{array}$} & \multicolumn{2}{|c|}{ Reindl Model } & \multicolumn{2}{|c|}{$\begin{array}{l}\text { Hay and Davis, Reindl } \\
\text { and klucher model }\end{array}$} \\
\hline & $\begin{array}{l}\text { Optimu } \\
\text { m tilt } \\
\text { angle } \\
\left(^{\circ}\right)\end{array}$ & $\begin{array}{c}\text { Irradiati } \\
\text { on } \\
\text { (kWh/m } \\
2_{\text {-day) }}\end{array}$ & $\begin{array}{l}\text { Optim } \\
\text { um tilt } \\
\text { angle } \\
\left(^{\circ}\right)\end{array}$ & $\begin{array}{c}\text { Irradiati } \\
\text { on } \\
\text { (kWh/m } \\
{ }^{2} \text {-day) }\end{array}$ & $\begin{array}{c}\text { Optimu } \\
\text { m tilt } \\
\text { angle } \\
\left(^{\circ}\right)\end{array}$ & $\begin{array}{c}\text { Irradiati } \\
\text { on } \\
\text { (kWh/m } \\
{ }^{2} \text {-day) }\end{array}$ & $\begin{array}{l}\text { Optimu } \\
\text { m tilt } \\
\text { angle } \\
\left(^{\circ}\right)\end{array}$ & $\begin{array}{l}\text { Irradiati } \\
\text { on } \\
\text { (kWh/m } \\
{ }^{2} \text {-day) }\end{array}$ & $\begin{array}{l}\text { Optimu } \\
\text { m tilt } \\
\text { angle } \\
\left(^{\circ}\right)\end{array}$ & $\begin{array}{l}\text { Irradiati } \\
\text { on } \\
\text { (kWh/m } \\
{ }^{2} \text {-day) }\end{array}$ & $\begin{array}{c}\text { Optimum } \\
\text { tilt angle } \\
\left(^{\circ}\right)\end{array}$ & $\begin{array}{c}\text { Irradiati } \\
\text { on } \\
\text { (kWh } / \mathrm{m}^{2} \\
\text {-day) }\end{array}$ \\
\hline January & 40 & 5.48 & 40 & 5.55 & 30 & 5.37 & 40 & 6.22 & 40 & 5.80 & 40 & 5.85 \\
\hline February & 30 & 6.44 & 30 & 5.52 & 30 & 5.34 & 30 & 6.15 & 30 & 6.68 & 30 & 6.68 \\
\hline March & 20 & 6.65 & 10 & 6.66 & 10 & 6.64 & 10 & 7.19 & 10 & 6.72 & 10 & 6.71 \\
\hline May & 20 & 5.57 & 10 & 5.58 & 10 & 5.55 & 10 & 5.83 & 10 & 5.54 & 10 & 5.54 \\
\hline June & 0 & 6.27 & 10 & 6.25 & 10 & 6.24 & 10 & 6.44 & 10 & 6.19 & 10 & 6.19 \\
\hline July & 0 & 5.15 & 0 & 5.16 & 0 & 5.16 & 0 & 5.41 & 0 & 5.16 & 0 & 5.16 \\
\hline August & 0 & 5.21 & 0 & 5.21 & 0 & 5.21 & 0 & 5.49 & 0 & 5.24 & 0 & 4.68 \\
\hline September & 10 & 5.53 & 10 & 5.53 & 10 & 5.51 & 10 & 5.83 & 10 & 5.55 & 10 & 5.54 \\
\hline October & 10 & 4.58 & 10 & 4.58 & 10 & 4.55 & 10 & 4.56 & 10 & 4.93 & 10 & 4.93 \\
\hline November & 10 & 4.10 & 10 & 4.10 & 10 & 4.08 & 10 & 4.31 & 10 & 4.11 & 10 & 4.11 \\
\hline December & 40 & 3.33 & 40 & 3.42 & 40 & 3.13 & 30 & 3.78 & 40 & 3.56 & 40 & 3.58 \\
\hline
\end{tabular}


For experimental validation, a 250W PV panel of poly crystalline type is taken and the maximum energy obtained is calculated for various tilting $\left(0^{\circ}-90^{\circ}\right)$ angle throughout a day with 10 minutes time interval. The test has been conducted throughout a year and the tilting angle in which the maximum energy received is considered as optimum one. The parameters of the panel are given in Table 5.

Table 5. Parameters of the solar panel used for experiment

\begin{tabular}{lc}
\hline \multicolumn{1}{c}{ Parameters } & Rating \\
\hline Maximum Power rating of the panel & $250 \mathrm{~W}$ \\
maximum power point voltage $\left(\mathrm{V}_{\mathrm{Mpp}}\right)$ & $36.5 \mathrm{~V}$ \\
maximum power point Current $\left(\mathrm{I}_{\mathrm{Mpp}}\right)$ & $6.8 \mathrm{~A}$ \\
Open circuit Voltage $(\mathrm{VOC})$ & $44.2 \mathrm{~V}$ \\
Short circuit current $\left(\mathrm{I}_{\mathrm{sc}}\right)$ & $7.6 \mathrm{~A}$ \\
\hline
\end{tabular}

In Table 6 comparison of predicted tilt angle using Liu-Jordan model and the optimum tilt angle calculated experimentaly were given. It is also clearly understood from the table, in summer and autumn seasons the panels can be fixed at minimum tilting angle due to the constant irradiance. In the winter and the spring season irradiance varies due to erratic weather conditions hence it is necessary to tilt the panel for high tilting angle to harvest maximum energy. Comparison of both fixed tilt and variable tilt is shown Figure 9. It is clear from the figure that the seasonal tilt gives the highest value of monthly average of daily global irradiation compared to the fixed tilt.

Table 6. Comparison of predicted tilt angle using Liu-Jourdan model and measured optimum tilt angle for

\begin{tabular}{|c|c|c|c|c|c|}
\hline Period & Months & $\begin{array}{c}\text { Predicted Seasonal tilt } \\
\text { angle (in degrees) }\end{array}$ & $\begin{array}{c}\text { Irradiation } \\
\left(\mathrm{kWh} / \mathrm{m}^{2} \text {-day }\right) \\
\end{array}$ & $\begin{array}{l}\text { Measured tilt angle } \\
\text { (in degrees) }\end{array}$ & MAPE(\%) \\
\hline \multirow[t]{2}{*}{ Winter } & December & \multirow[t]{3}{*}{ 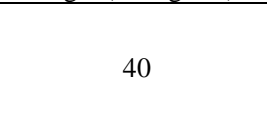 } & 5.48 & \multirow{3}{*}{35} & \multirow{3}{*}{12} \\
\hline & $\begin{array}{l}\text { January } \\
\text { February }\end{array}$ & & $\begin{array}{l}6.45 \\
6.65\end{array}$ & & \\
\hline Spring & March & & 5.93 & & \\
\hline & $\begin{array}{l}\text { April } \\
\text { May }\end{array}$ & 20 & $\begin{array}{l}5.57 \\
6.27\end{array}$ & 22 & 10 \\
\hline \multirow[t]{2}{*}{ Summer } & June & \multirow{3}{*}{0} & 5.16 & \multirow{3}{*}{0} & \multirow{3}{*}{0} \\
\hline & $\begin{array}{c}\text { July } \\
\text { August }\end{array}$ & & $\begin{array}{l}5.21 \\
5.53\end{array}$ & & \\
\hline \multirow[t]{2}{*}{ autumn } & September & & 4.58 & & \\
\hline & $\begin{array}{l}\text { October } \\
\text { November }\end{array}$ & 10 & $\begin{array}{l}4.10 \\
3.33\end{array}$ & 10 & 0 \\
\hline
\end{tabular}

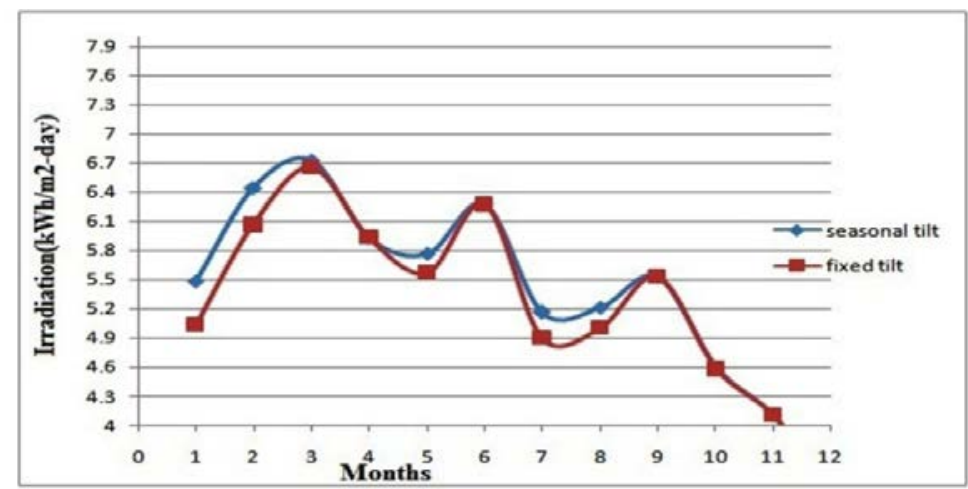

Figure 9. Comparison of fixed tilt and seasonal tilt

\section{CONCLUSION}

The estimation of solar irradiation in two different panel positions such as fixed tilt and seasonal tilt are carried out in SASTRA, Thanjavur (India) location. The following prominent aspects are observed and inferred during the experimental work: 
1. Experimental results indicate that when seasonal tilting of the panel is employed, the irradiation obtained is maximum compare to the fixed tilting of the panel. For the locations situated in southern region of India, maximum energy has been harvested if the panel is tilted to the optimum tilt angle for every three months once in a year.

2. It is also pertinent to note that in all the statistical tests the Liu-Jordan model exhibits very low error rate and hence suitable for the locations in south India.

\section{ACKNOWLEDGEMENTS}

The authors of this work are extremely thankful to Management of SASTRA University for the support and motivation extended to them during the research.

\section{REFERENCES}

[1] http://www.enfsolar.com/pv/panel-datasheet/Polycrystalline/16685

[2] M. Sadhu, et al., "Role of Solar Power in Sustainable Development of India,” TELKOMNIKA Indonesian Journal of Electrical Engineering, vol/issue: 14(1), pp. 34-41, 2015.

[3] J. Krautmann and J. Zhu, "Photovoltaic Solar Energy Systems: Market Trends in the United States,” International Journal of Applied Power Engineering, vol/issue: 1(3), pp. 123-128, 2012.

[4] M. Louzazni, et al., "Modeling and Simulation of a Solar Power Source for a Clean Energy without Pollution," International Journal of Electrical and Computer Engineering, vol/issue: 3(4), pp. 568-576, 2013.

[5] K. Skeiker, "Optimum tilt angle and orientation for solar collectors in Syria," Energy Conversion and Management, vol. 50, pp. 2439-2448, 2009.

[6] C. S. Solanki, "Solar Photovoltaics Fundamentals, Technologies and Applications," Delhi, PHI learning private limited, 2009.

[7] J. A. Duffie, et al., “Solar Engineering of Thermal Processes,” 2nd ed., Canada, John Wiley \& Sons Inc, 1991.

[8] A. A. E. Sebaii, et al., "Global, direct and diffuse solar radiation on horizontal and tilted surfaces in Jeddah, Saudi Arabia,” Applied Energy, vol. 87, pp. 568 - 576, 2010.

[9] D. H. W. Li and T. N. T. Lam, "Determining the Optimum Tilt Angle and Orientation for Solar Energy Collection Based on Measured Solar Radiance Data,” International Journal of Photoenergy, 2007.

[10] G. Lewis, “Optimum tilt of a solar collector,” Solar \& Wind Technology, vol/issue: 4(3), pp. 407-410, 1987.

[11] Yellott, "Utilization of sun and sky radiation for heating and cooling of buildings," ASHRAE Journal, vol. 15, pp. 31-42, 1973.

[12] H. P. Garg and U. Rani, “Theoretical and experimental studies on collector/storage type solar water heater,” Solar Energy, vol. 29, pp. 467-478, 1982.

[13] Mohd Azmi bin Hj Mohd Yakup and A. Q. Malik, "Optimum tilt angle and orientation for solar collector in Brunei Darussalam,” Renewable Energy, vol. 24, pp. 223-234, 2001.

[14] A. Chatterjee and A. Keyhani, "Neural Network Estimation of Micro grid Maximum Solar Power," IEEE Transactions on Smart Grid, vol/issue: 3(4), pp. 1860-1866, 2012.

[15] M. M. E. Kassaby, "Monthly and Daily Optimum Tilt Angle for South Facing Solar Collectors, Theoretical Model, Experimental and Empirical Correlations,” Solar \& Wind Technology, vol/issue: 5(6), pp. 589-596, 1988.

[16] M. M. E. Kassaby and M. H. Hassab, "Investigation of Variable Tilt Angle Australian Type Solar Collector. Renewable Energy,” vol/issue: 4(3), pp. 327-332, 1994.

[17] K. N. Shukla, et al., "Comparative study of isotropic and anisotropic sky models to estimate solar radiation incident on tilted surface: A case study for Bhopal, India,” Energy Reports, vol. 1, pp. 96-103.

[18] E. D. Mehleri, et al., "Determinations of the Optimal tilt angle and orientation for solar photovoltaic arrays," Renewable Energy, vol. 35, pp. 2468-2475, 2010.

[19] J. S. Armstrong, "Long-Range Forecasting: From Crystal Ball to Computer," 2 edition, Wiley-Interscience, 1985.

[20] J. Kaldellis, et al., "Experimental validation of the optimum photovoltaic panels tilt angle for remote consumers," Renewable Energy, vol. 46, pp. 179-191, 2012.

[21] R. Kumar and L. Umanand, "Estimation of global radiation using clearness index model for sizing photovoltaic System,” Renewable Energy, vol. 30, pp. 2221-2233, 2005.

[22] T. V. Dixit, et al., "Optimization of PV array inclination in India using ANN estimator method comparison study," Sadhana, vol/issue: 40(5), pp. 1457-1472, 2015.

[23] O. S. Idowu, et al., "Determination of optimum tilt angles for solarcollectors in low-latitude tropical region," International Journal of Energy and Environmental Engineering, vol/issue: 4(29), 2013. 


\section{BIOGRAPHIES OF AUTHORS}

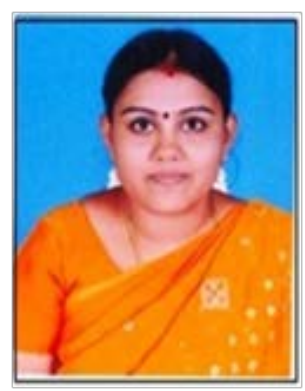

K.Parkavi kathirvelu was born in Kumbakonam, Tamilnadu, India, in 1981. She received the B.E degree in electrical and electronics engineering from the University of Madras, India, in 2002 and the M.Tech degree in Power electronics and Drives from SASTRA University, Thanjavur, India in 2004. Presently she is working as a Assistant Professor at the Department of Electrical and Electronics Engineering, School of Electrical and Electronics Engineering SASTRA University. His research interests include Power quality improvements, Power electronics and microgrid system.

E.mail:to_parkavi@eee.sastra.edu

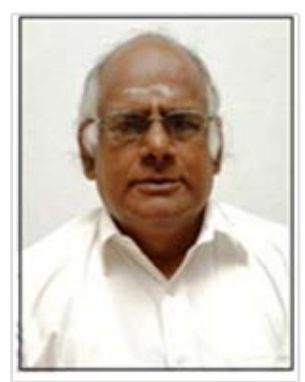

Dr.B.Viswanathan is currently working as Dean, School of Electrical and Electronics Engineering in SASTRA University. He has over 25 Years of teaching and research experience in various areas of power systems. His areas of interest are Distributed generation, Distributed automation and Smart grid.

E.Mail:deanbv@sastra.edu 